
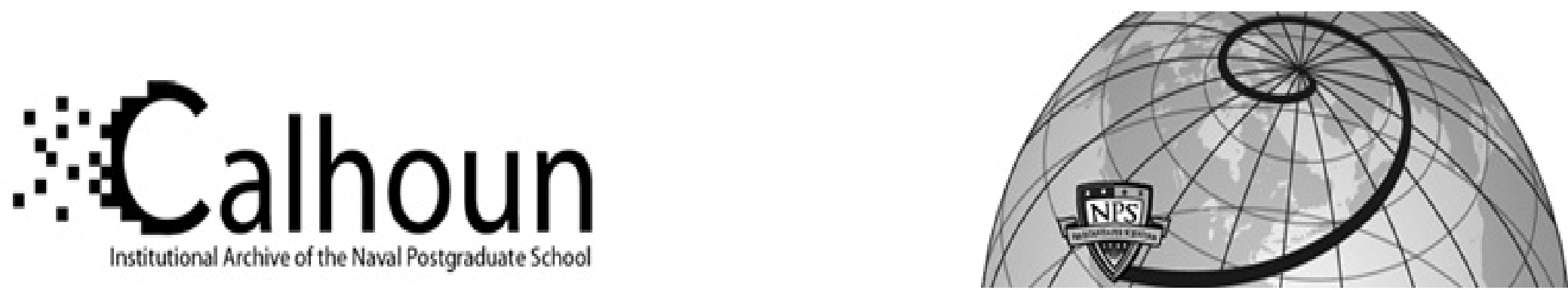

Calhoun: The NPS Institutional Archive DSpace Repository

The Relative Efficacy of Monetary and Fiscal Policy in Saudi Arabia

Looney, R.E.

Looney, R.E., "The Relative Efficacy of Monetary and Fiscal Policy in Saudi Arabia," Journal of International Development, July, 1989.

https://hdl.handle.net/10945/40561

This publication is a work of the U.S. Government as defined in Title 17, United States Code, Section 101. Copyright protection is not available for this work in the United States.

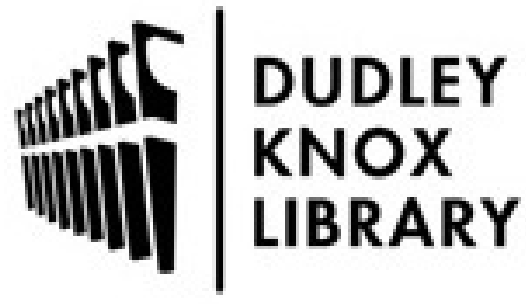

http://www.nps.edu/library
Calhoun is the Naval Postgraduate School's public access digital repository for research materials and institutional publications created by the NPS community. Calhoun is named for Professor of Mathematics Guy K. Calhoun, NPS's first appointed -- and published -- scholarly author.

Dudley Knox Library / Naval Postgraduate School 411 Dyer Road / 1 University Circle Monterey, California USA 93943 


\title{
THE RELATIVE EFFICACY OF MONETARY AND FISCAL POLICY IN SAUDI ARABIA
}

\author{
ROBERT E. LOONEY \\ Naval Postgraduate School, Monterey, California, USA
}

\section{INTRODUCTION}

Traditionally, discussions of macroeconomic policy in developing countries have stressed the growing interdependence of monetary and fiscal policy: fiscal policy consisting of measures related to central and local government revenue and expenditures, while monetary policy involves measures which affect the supply of money and credit and the rate of interest (Eshag, 1983).

Since the 1973/74 oil price increases, Saudi Arabian officials have had the luxury of pursuing monetary and fiscal policies in a relatively unconstrained environment. Particularly during the period up to 1982 , Saudi officials had not given serious attention to the issue of the relative efficacy of monetary or fiscal policy. The only real policy dilemma in this regard was perhaps the government's anti-inflation programme in the late 1970s (Looney, 1986).

In light of the post-1982 decline in oil revenues, Saudi authorities have been increasingly forced to re-evaluate the potential for improvement in macroeconomic policy making. In this regard, the pertinent questions are:

1. What is the relative potential of fiscal and monetary policy for promoting economic growth in Saudi Arabia?

2. To what extent has this potential been exploited? and

3. Could past economic performance have been superior if a different mix of monetary and fiscal policies were preposed.

Presumably if the answer to the last question is yes, the fall in income associated with the recent oil revenue declines need not have been as great as experienced.

The purpose of the analysis below, given the institutional environment in which macroeconomic policy is pursued in Saudi Arabia, is to determine: 
1. The relative efficacy of past monetary and fiscal policies in the kingdom.

2. The relative merits of pursuing monetary or fiscal policy while limiting the discretion of policy makers i.e. the relative effectiveness of rules versus authorities.

3. The extent to which one policy mix has been superior to alternative combinations.

Saudi Arabia presents an interesting case study because many of the general principles associated with monetary and fiscal policy are not applicable:

1. There is no interest rate per se for monetary policy to affect (due to religious restrictions on the payment or receipt of interest).

2. The government does not use tax policy as an integral element in its fiscal programme (due to the abundance of oil revenues and the traditional use of the Zekat or wealth tax.

3. The government (because of the abuses in the 1950s) is very reluctant to run budget deficits in the traditional sense (AlTimimi, 1985).

\section{RELATIVE STABILITY OF VELOCITY AND THE INVESTMENT MULTIPLIER}

Intuitively, given the importance of oil revenues and government expenditures as a driving force in the Saudi Arabian economy, one might expect that monetary expansion should, at most play a secondary role in affecting the level of real output. For example Kernan and Malik $(1979$, p.5) argue that in the Saudi Arabian context:

1. Real income is dependent upon the ability to import goods and services rather than the ability to produce goods and services (other than oil).

2. Government spending, even with a budget surplus, can still imply stimulative fiscal policy because most government revenues come from abroad; and

3. Stimulative fiscal policy leads directly to an increase in the money supply because of the underlying structure of their country's financial markets i.e., their general underdevelopment.

In fact several observers (Ferkat, 1979; and Morgan, 1979) have even gone so far as to refer to Saudi Arabia as one of the purest present day examples of a classic Keynesian type economy. Still it is impossible that by itself monetary expansion, perhaps induced by the Saudi Arabian monetary Authority (SAMA) through lowering of the reserve requirement, could and 
has made an independent contribution toward inducing monetary growth (thus inducing increased expenditures in the non-oil sector of the economy).

To test for the relative strength of money and autonomous expenditures in inducing expenditures in the Saudi Arabian context a simple model was specified and estimated:

(I) $\mathrm{DE}=\mathrm{aDM}+\mathrm{bDA}+\mathrm{c}$

(II) $\mathrm{DE}=\mathrm{eDML}+\mathrm{fDAL}+\mathrm{g}$

Where DE is the change in induced expenditures in period t, and DM is the change in the supply of money in period $t$.

Since there is some controversy over the appropriate definition of induced and autonomous expenditures, two alternative definitions were tested:

(a) $\mathrm{A} 1=\mathrm{TIN}+\mathrm{GCN}+\mathrm{EXPTN}-\mathrm{ZN}+\mathrm{NFPN}$

(b) $\mathrm{A} 2=\mathrm{ION}+\mathrm{GIN}+\mathrm{GCN}+\mathrm{EXPTN}-\mathrm{ZN}+\mathrm{NFPN}$

where: TIN $=$ total gross capital formation; $\mathrm{GCN}=$ government consumption: $\mathrm{ZN}=$ imports; NFPN $=$ net factor payments: $\mathrm{ION}=$ investment in the oil industry; GIN = government investment; and A1 and A2 $=$ autonomous expenditures.

The differences between the two types of autonomous expenditure defined above is the inclusion of private investment in the first measure (A1), but not in the second (A2). Given these definitions of autonomous expenditures, two measures of induced expenditures were derived:

(c) $\mathrm{E} 1=\mathrm{GNP}-\mathrm{A} 1$.

(d) ${ }^{-} \mathrm{E} 2=\mathrm{GNP}-\mathrm{A} 2$.

where GNP is the gross national product. E1 contains private consumption and the change in inventories, while E2 contains private consumption, private investment, and the change in inventories.

The results obtained by regressing the change in autonomous expenditures and money on induced expenditure were quite striking. ${ }^{1}$

1. $\mathrm{DE} 1=0.03 \mathrm{DA} 1+0.98 \mathrm{DM} 1-0.31 \mathrm{RHO}$
$(0.64)$
(2.93)
$(-1.62)$

$\mathrm{r} 2=0.281 ; \mathrm{F}=3.13 ; \mathrm{DW}=2.16$

2. $\mathrm{DE} 1=0.02 \mathrm{DA} 1+0.91 \mathrm{DM} 2-0.45 \mathrm{RHO}$

(0.50) (3.48) (-2.32)

$\mathrm{r} 2=0.455 ; \mathrm{F}=6.42 ; \mathrm{DW}=2.45$

3. $\mathrm{DE} 1=0.03 \mathrm{DA} 1+0.81 \mathrm{DM} 3-0.50 \mathrm{RHO}$

$(0.90) \quad(3.92) \quad(-2.64)$

$\mathrm{r} 2=0.503 ; \mathrm{F}=8.10 ; \mathrm{DW}=2.56$

4. $\mathrm{DE} 2=0.04 \mathrm{DA} 2+1.30 \mathrm{DM} 1-0.24 \mathrm{RHO}$

(0.83) (2.87) (1.13)

$\mathrm{r} 2 \pm 0.357 ; \mathrm{F}=44.44 ; \mathrm{DW}=2.13$ 
5. $\mathrm{DE} 2=0.02 \mathrm{DA} 2+1.18 \mathrm{DM} 2-0.39 \mathrm{RHO}$

(0.72) (4.33) (-1.91) $\mathrm{r} 2=0.551 ; \mathrm{F}=9.93 ; \mathrm{DW}=2.46$

6. $\mathrm{DE} 2=0.04 \mathrm{DA} 2+1.04 \mathrm{DM} 3-0.47$ RHO

(1.22) (5.03) (-2.37)

$\mathrm{r} 2=0.621 ; \mathrm{F}=13.08 ; \mathrm{DW}=2.56$

Contrary to the received literature, changes in the money supply rather than changes in autonomous expenditures appear to have the greatest stimulative effect on induced expenditures. This conclusion holds irrespective of the definition of money or the definition of autonomous expenditures.

The results indicate that there is some improvement in the specification by including private investment as part of induced expenditures. Obviously, this finding confirms official concern over possible declines in private investment brought about by capital outflows to Bahrain and other international financial centers.

Finally the results indicate not only the relative importance of money in stimulating private sector demand, but point out the possibility of keeping the economy, even during a period of falling oil revenues, somewhat buoyant through monetary expansion. The implications for government policy are rather optimistic in the sense that, with increased financial reform and the development of traditional tools of monetary policy for SAMA, control of the money supply should take considerable pressure off fiscal policy as a means of preventing deflation during the current oil price slump.

\section{Options for SAUdi ARabian Macroeconomic Policy}

What is appropriate monetary policy for a growing economy such as Saudi Arabia's? Ultimately this becomes an empirical issue, whereby past economic performance can be simulated and assessed in terms of alternative policy strategies. The results obtained above indicate a new and potentially important role for monetary policy in Saudi Arabia's stabilization efforts. However, several technical issues would need to be addressed. The first involves whether policy-makers ought to be confined to a simple rule for monetary expansion, or whether their stabilization efforts would be better served by applying discretionary changes in the money supply.

Operationally, the simple Cambridge version of the quantity theory of money was the original basis for monetary rules (Friedman and Schwartz, 1963). According to the Cambridge theory, the nominal demand for money (Md) is a stable function (Tavlas and Ascheim, 1981) which is assumed to vary inversely with the market rate of interest of nominal income (Y). Since nominal income is the product of real output (y) and the price level (p), it follows that: 
1. $\mathrm{Md}=\mathrm{kY}=\mathrm{kyp}$.

If we further assume that the supply of money Ms is determined by the authorities so that $\mathrm{Ms}=\mathrm{Md}$, then the equilibrium condition becomes:

2. $\quad \mathrm{Ms}=\mathrm{kyp}$.

Equation (2) states that given the value of $\mathbf{k}$ and $\mathbf{y}$, the money supply determines the price level; ie., that real output is independent of the money supply in the long run. In the short run, however, the monetary sector is likely to affect output because the price level will usually not fully adjust instantaneously to eliminate discrepancies between the supply and demand for money. Also, since not all prices are likely to change at the same rate, relative prices and the pattern of production may also be distorted in the short run.

Equation (2) suggests that Saudi Arabian monetary policy should concentrate on manipulating the money supply so as to foster the desired behaviour of output and the price level. This in turn requires offsetting any changes in the proportion of income held in monetary balances $(k)$ which in turn may threaten to create undesirable movements in the money demandsupply relationship.

Since growth in output over time takes place as population, labour, productivity, capital and technology increase, equation (2) is best formulated as percentage rates of change.

(3) $\mathrm{gm}=\mathrm{gk}+\mathrm{gy}+\mathrm{gp}$

Monetary growth (gm) is best targeted at the rate of growth of full employment output (gy) plus the desired rate of inflation (gp) plus or minus the rate at which the demand for money (gk) might be changing. Using this general framework, Bronfenbrenner (1961) and Modigliani (1964) have proposed alternative tests for determining the relative effectiveness of monetary rules and discretionary monetary control.

\section{The Bronfenbrenner Test}

Bronfenbrenner's approach assumes that neither the growth in real income nor the rate in change in velocity is sensitive to relatively small variations in the rate of change in money. It follows that the ideal rate of monetary growth, $\mathrm{dMo} / \mathrm{Mo}$ is:

4. $\mathrm{dMo} / \mathrm{Mo}=\mathrm{dY} / \mathrm{Y}-\mathrm{dV} / \mathrm{V}=\mathrm{DM} / \mathrm{M}-\mathrm{dP} / \mathrm{P}$

The rate of inflating $\mathrm{dPr} / \mathrm{Pr}$ due to the operation of a simple rule of constant monetary growth becomes:

5. $\mathrm{dMr} / \mathrm{Mr}=\mathrm{dPr} / \mathrm{Pr}+\mathrm{dY} / \mathrm{Y}-\mathrm{dV} / \mathrm{V}$

where: $\mathrm{dMr} / \mathrm{Mr}$ represents some constant rate of increase in money. If $\mathrm{dY} / \mathrm{Y}$ and $\mathrm{dV} / \mathrm{V}$ are known, the equation can be solved for $\mathrm{dPr} / \mathrm{Pr}$. 
The errors in the actual monetary growth would be:

6. $\mathrm{dM} / \mathrm{M}=\mathrm{dMo} / \mathrm{Mo}=\mathrm{dM} / \mathrm{M}-\mathrm{dYo} / \mathrm{Yo}+\mathrm{dV} / \mathrm{V}$

where $d Y_{0} / Y o$ represents the growth in full capacity output. Substituting (1)

for $\mathrm{dM} / \mathrm{M}$ :

7. $\mathrm{dM} / \mathrm{M}-\mathrm{dMo} / \mathrm{Mo}=\mathrm{dP} / \mathrm{P}-(\mathrm{dYo} / \mathrm{Yo}-\mathrm{dY} / \mathrm{Y})$

Since $(\mathrm{dYo} / \mathrm{Yo})-(\mathrm{dYo} / \mathrm{Yo})$ represents the output slack, the error in actual monetary growth is equal to the actual rate of inflation less the difference in output.

The judgement rule can now be contrasted with that obtained with the application of a simple monetary growth rule by comparing the errors in (5) with those obtained in (4). As a variant, Bronfenbrenner's lag formula specifies the rate of growth of money supply to be adjusted in accordance with the prior year's fluctuations in the growth of real output and income velocity.

The most logical type of test for alternative monetary policies is the mean algebraic deviation (MAD) of the alternative growth rate from the target growth rate (the rate of growth which generates a zero rate of price increase). According to this test, the rule under consideration outperforms its rivals if it has the smaller MAD (In addition to a smaller standard deviation).

The results (Table 1) of applying Bronfenbrenner's criteria to the Saudi Arabian economy reveal several distinct patterns:

(i) In general, rules outperforms discretion (both in terms of the mean and standard deviation.

(ii) The lag rule tends to outperform the constant growth rule in terms of the mean, but not on the basis of the standard deviation.

(iii) In terms of the various measures of money, M1 tends to produce a lower MAD than either M2 or M3, but its standard deviation is slightly higher than those obtained by the other two measures of money.

A number of objections may be raised against Bronfenbrenner's test. One is the assumption that both real output and velocity are not affected by changes in money. Another difficulty with Bronfenbrenner's test is that the simple rule is assumed to be superimposed in each year on top of the actual money supply obtaining at the beginning of the year. Yet if the rule had in fact been implemented in the earlier years, the money supply would have been quite different from that actually prevailing at the start of the year.

\section{The Modigliani Test}

Modigliani's test attempts to overcome several of the limitations inherent in Bronfenbrenner's test. Using Bronfenbrenner's framework, Modigliani defines $(\mathrm{dMo} / \mathrm{Mo})$ in terms of aezero rate of inflation as well as a 
satisfactory level of employment. The critical equation in the Modigliani test is:

8. $\mathrm{dMo} / \mathrm{Mo}=\mathrm{dYo} / \mathrm{Yo}-\mathrm{dV} / \mathrm{V}$

where the rate of inflation is again set at zero. In this case $d Y o / Y o$ represents the rate of growth of real output consistent with the full employment of resources. As in the Bronfenbrenner test, velocity is again assumed to be

Table 1.

SAUDI ARABIA: DEVIATION OF ALTERNATIVE MONETARY POLICIES FROM THE IDEAL PATTERN, 1965-85, BRONFENBRENNER TEST

\begin{tabular}{|c|c|c|c|c|c|c|c|}
\hline & \multicolumn{3}{|c|}{$\begin{array}{c}\text { Constant Growth Rate } \\
\text { Rate }=10 \%\end{array}$} & \multicolumn{3}{|c|}{ Lag Rule } & \multirow{2}{*}{$\begin{array}{c}\text { Discretion } \\
\end{array}$} \\
\hline & MI & $M 2$ & $M 3$ & $M I$ & $M 2$ & $M 3$ & \\
\hline 1965 & 2.5 & 1.5 & -0.4 & -7.5 & -8.5 & -10.3 & 0.0 \\
\hline 1966 & -2.6 & -3.4 & -2.8 & -4.9 & -4.8 & -2.5 & 1.1 \\
\hline 1967 & -1.2 & -3.7 & -4.2 & 1.2 & -0.6 & -1.6 & 2.2 \\
\hline 1968 & 4.3 & 0.4 & 1.5 & -0.7 & -2.5 & -11.8 & 2.2 \\
\hline 1969 & 5.7 & 3.6 & 5.2 & 9.5 & 10.7 & 11.4 & 3.2 \\
\hline 1970 & 9.3 & 5.6 & 6.1 & 1.3 & -0.3 & -1.4 & 2.0 \\
\hline 1971 & 1.6 & -1.7 & -1.1 & -7.7 & -5.5 & -7.2 & 2.0 \\
\hline 1972 & -9.0 & -9.2 & -10.8 & 10.8 & -8.2 & -10.3 & 4.9 \\
\hline 1973 & -20.0 & -14.0 & -15.3 & -14.5 & -7.6 & -7.8 & 9.4 \\
\hline 1974 & -12.6 & -8.7 & -13.2 & 2.3 & 1.8 & -1.8 & 18.0 \\
\hline 1975 & 5.6 & 6.7 & 7.7 & 14.3 & 12.4 & 16.5 & 61.6 \\
\hline 1976 & -34.3 & -25.3 & -24.3 & -42.2 & -33.5 & -34.1 & 40.4 \\
\hline 1977 & -27.4 & -23.9 & -19.6 & -0.9 & -3.3 & 1.0 & 22.4 \\
\hline 1978 & -17.7 & -18.1 & -16.0 & -4.7 & -2.7 & -3.1 & 15.9 \\
\hline 1979 & 3.4 & 1.2 & 0.7 & 15.5 & 13.5 & 11.7 & 7.2 \\
\hline 1980 & 7.3 & -0.7 & -1.1 & 3.6 & -2.2 & -2.2 & 9.2 \\
\hline 1981 & 5.0 & -8.8 & -10.6 & -2.2 & -8.8 & -7.3 & 6.7 \\
\hline 1982 & -4.0 & -7.8 & -9.8 & -9.0 & -1.0 & -1.6 & 5.6 \\
\hline 1983 & 1.1 & 1.7 & 1.4 & 4.1 & 8.8 & 8.8 & 3.9 \\
\hline 1984 & 10.2 & 7.7 & 3.1 & 8.6 & 4.6 & 1.4 & -0.7 \\
\hline 1985 & 10.0 & 5.6 & 4.3 & -0.1 & -2.1 & 1.0 & -2.0 \\
\hline Mean & -3.0 & -4.3 & -4.8 & -1.7 & -1.6 & -2.0 & 10.2 \\
\hline $\mathrm{SD}$ & 12.7 & 9.6 & 9.2 & 12.3 & 10.1 & 10.6 & 15.3 \\
\hline
\end{tabular}

Notes: See text for method of computation. Monetary series taken from Saudi Arabian Monetary Authority Annual Report, various issues. SD = standard deviation. 
invariant to the rate of change in the money supply. The errors in this test are simply the difference between the ideal money supply and the money supply dictated by the rule (constant velocity rates).

9. $\mathrm{dMr} / \mathrm{Mr}-\mathrm{dMo} / \mathrm{Mo}=\mathrm{dMr} / \mathrm{Mr}-\mathrm{dYo} / \mathrm{Yo}+\mathrm{dV} / \mathrm{V}$

These errors can be calculated for each year since $\mathrm{dMr} / \mathrm{Mr}, \mathrm{dYo} / \mathrm{Yo}$ and $\mathrm{dV} / \mathrm{V}$ are all known. In order to define the target price level, we need to operationally define Modigliani's rather vague notion of 'stabilizing the price level?' Following Modigliani, we define this concept operationally by identifying the target price level in the period ( $t$ ) with the level ruling at the beginning of the period; i.e., the price level ending the previous time period.

The results of Modigliani's procedure (Table 2) for 1965-85 are in general supportive of those found in the Bronfenbrenner method:

1. Again the simple monetary growth rules greatly outperforms discretion.

2. For the 1965-85 period, a constant expansion of the money supply around 10 per cent seems to produce a MAD fairly close to zero and a significantly lower standard deviation than for discretionary policy.

3. Again, M1 tends to produce a lower mean than either M2 or M3, but at the same time has a higher standard deviation.

\section{Summary}

In summarizing the results obtained above:

1. The foregoing evidence suggests that in Saudi Arabia's case, the relationship between money and economic activity is more predictable than that stemming from changes in autonomous expenditures.

2. Discretionary monetary policy is inferior to a fixed and steady expansion of the money supply.

3. The fixed expansion rule is superior irrespective of the method of analysis; and

4. The results seem to be in contrast to those of the United States where Modigliani's findings favoured discretion (although Bronfenbrenner's findings favoured rules in the conduct of monetary policy).

\section{Optimal Control Simulations}

It is easy to argue that the tests above are not 'fair' to the use of policy discretion in Saudi Arabia. Clearly in the post-1973/74 oil boom the authorities did not pursue a systematic policy of planned spending - there was a great deal of undisciplined spending of thessurplus oil revenues, a situation 
unlikely to be duplicated in the near future. In retrospect, therefore, can Saudi policy makers identify from past performance a discretionary fiscal policyrule that is superior to the one previously pursued (and presumably appropriate for future policy making)?

One operational way of resolving this issue is through the use of optimal control simulations of past macroeconomic environments (Motamen, 1979; Looney, 1987). Here the essential idea is to derive an optimal policy in order

Table 2.

SAUDI ARABIA: DEVIATION OF ALTERNATIVE MONETARY POLICIES FROM THE IDEAL PATTERN, 1965-85, MODIGLIANI TEST

\begin{tabular}{|c|c|c|c|c|c|c|}
\hline & \multicolumn{3}{|c|}{$\begin{array}{c}\text { Constant Growth Rate } \\
\text { Rate }=10 \%\end{array}$} & \multicolumn{3}{|c|}{ Lag Rule } \\
\hline & $M I$ & $M 2$ & $M 3$ & $M I$ & $M 2$ & $M 3$ \\
\hline 1965 & 2.3 & 1.3 & -0.4 & -0.2 & -0.2 & 0.0 \\
\hline 1966 & -2.3 & -3.1 & -2.6 & 1.4 & 1.5 & 1.4 \\
\hline 1967 & 4.9 & 2.8 & 13.3 & 8.2 & 8.7 & 19.6 \\
\hline 1968 & -3.8 & -7.2 & -6.2 & -5.8 & -5.4 & -5.6 \\
\hline 1969 & 8.0 & 5.9 & 7.4 & 5.4 & 5.5 & .5 .4 \\
\hline 1970 & 9.3 & 3.7 & 6.1 & 2.0 & 0.2 & 2.1 \\
\hline 1971 & -1.8 & -1.0 & -0.4 & 2.3 & 2.7 & 2.7 \\
\hline 1972 & -6.2 & -6.4 & -7.6 & 7.7 & 7.7 & 8.1 \\
\hline 1973 & -14.9 & -10.4 & -11.4 & 15.2 & 12.9 & 13.3 \\
\hline 1974 & -8.7 & -5.7 & -8.8 & 21.9 & 20.9 & 22.3 \\
\hline 1975 & 7.9 & 8.3 & 8.8 & 63.9 & 63.2 & 62.7 \\
\hline 1976 & -26.5 & -20.6 & -20.6 & 48.1 & 45.1 & 45.1 \\
\hline 1977 & -17.3 & -15.4 & -12.8 & 32.5 & 30.9 & 29.1 \\
\hline 1978 & -12.1 & -12.4 & -11.0 & 21.6 & 21.7 & 20.9 \\
\hline 1979 & 3.6 & 1.5 & 1.1 & 7.3 & 7.5 & 7.6 \\
\hline 1980 & 7.2 & 0.0 & -3.3 & 9.2 & 10.0 & 7.9 \\
\hline 1981 & 5.9 & 6.9 & -8.2 & 6.7 & 8.7 & 9.1 \\
\hline 1982 & -3.0 & -7.0 & -7.4 & 6.6 & 6.4 & 7.9 \\
\hline 1983 & 1.5 & 3.1 & 1.7 & 4.4 & 5.3 & 4.3 \\
\hline 1984 & 10.2 & 7.7 & 3.3 & -0.6 & -0.7 & -0.4 \\
\hline 1985 & 10.0 & 5.8 & 4.5 & -2.0 & -1.8 & -1.7 \\
\hline Mean & -1.1 & -2.7 & -2.6 & 12.2 & 11.9 & 12.4 \\
\hline SD & 10.1 & 7.9 & 8.3 & 17.2 & 16.7 & 16.6 \\
\hline
\end{tabular}

Notes: $\quad$ See text for method of computation. Monetary series taken from Saudi Arabian Monetary Authority Annual Report, various issues. SD = standard deviation.

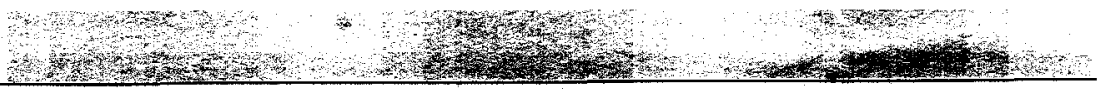


to steer the economy to a specific target. A necessary step in applying control theory is to specify an objective function or a welfare loss function by which the outcome associated with the optimal policy or its alternatives can be evaluated. Given a welfare loss function and a dynamic model, a policy sequence can be found minimizing the expectation of the welfare loss for a given time horizon.

\section{A Macroeconomic-Model of the Saudi Arabian Economy}

The model developed below is a simple simulation model designed to incorporate the possibilities of both discretionary and non-discretionary policy alternatives. The model contains 11 functional, endogenous equations. The main features of the model include (Table 3):

1. The money supply (in the non-rule version) is a direct function of government expenditures (equation 3).

2. Non-oil Gross Domestic Product is estimated by a quantity theory type function whereby the growth in real non-oil income is assumed dependent on the rate of growth in the money supply, the rate of growth in velocity and inversely to the consumer price index (equation 10).

3. Inflation is dependent on the growth in money, world (imported inflation) and (in the case of the non-oil GDP deflator) growth in income (equations 9 and 11).

4. The velocity of money (M1) increases with increased opporttnity cost of holding money (as proxied by the Euro interest rate and the expected rate of inflation).

In short, the model links the money supply with government expenditures. In light of the stability of the money multiplier demonstrated above, the growth in real non-oil GDP was in turn determined by the overall growth in the money supply, and any increase in the velocity of money. The stability of velocity (and hence the validity of the quantity model used here) was confirmed by the fact that regressions of the growth of money on the growth of velocity were not statistically significant.

Using this model, optimal control simulations of the economy over the 1965-85 period were performed. In each simulation the objective function chosen for optimisation was the rate of growth in non-oil income over the period under consideration. In contrast to the rules versus authorities tests of Bronfenbrenner and Modigliani, fiscal policy was not evaluated ex post. Instead, several fiscal environments were simulated in which general guidelines were specified as to the rate of increase in government expenditures. Within each of these environments, the policy outcomes using discretionary (optimal expenditure policies) fiscal policies were compared 


\section{Table 3.}

\section{SAUDI ARABIA: MONETARIST MACROECONOMIC SIMULATION} MODEL

(Two-stage least squares estimations)

(1) Growth in Oil Revenue (GGROX) $=0.85 \mathrm{GEN}+0.49 \mathrm{GENL}$

(9.27) (11.83)

(2) Growth in Non-oil Revenue (GNOR) $=0.83$ GGROX

(2.6)

(3) Growth in Government Revenue (GGRX) $=0.89$ GGROX +0.06 GNOR

$$
\text { (9.37) (2.09) }
$$

(4) Growth in Monetary System Foreign Assets (GMSFA) $=1.20$ GGROX

(5) Growth in Commercial Bank Credit to the Private Sector (GCBPS) $=$ 0.45 GGEX + 0.15 GMSFA
(2.28)
(1.94)

(6) Growth $=$ Government Deficit (GGDEF) $=$ GGRX - GGEX

(7) Growth $=$ Government Expenditures, National Accounts (GGENAN) $=$ 0.48 GGEX + 0.29 GGENANX + 0.15 GGROX
(2.83)
(1.98)
(2.06)

(8) Growth in Money Supply (GMIX) $=5.71+0.38$ GGEX +0.27 GGEXL

$$
\text { (2.04) (4.88) (3.68) }
$$

(9) Inflation; Non-oil GDP Deflation (INFN) $=$ 0.58 GMIX + 0.38 INFNL -0.45 GYX
(5.94)
(1.96)
$(-2.14)$

(10) Grown in Real Non-oil GDP (GYX) $=0.62$ GMIX + 1.04 GVM1X - 0.68 INFC

$$
\text { (4.87) (2.81) } \quad(-1.79)
$$

(11) Inflation; Consumer Price Index (INFC) $=0.25 \mathrm{GM} 1 \mathrm{X}-0.38 \mathrm{INFN}$

$$
\text { (5.47) (2.10) }
$$

(12) Growth in Velocity of Money $(\mathrm{GMIX})=0.32$ EUROR +0.18 INFNE

$$
\text { (2.11) (2.09) }
$$

(13) Expected Inflation (INFNE) $=$ INFNL - INFNL2

Exogenous Variables, World Inflation (INFW), Real Euro Interest Rate (EUROR), Exports (GEN) 
with those using arbitrary monetary rules. The fiscal environments used to constrain government expenditures were:

1. (I) The government budget (the growth in revenues minus the growth in expenditures) was allowed to vary with a range of plus minus 2.5 per cent.

2. (II) The government budget deficit (as defined above) was allowed to fluctuate over a range of plus minus five per cent.

3. (III) Government fiscal expansion was constrained to a rate consistent with inflation not rising above 10 per cent in any year. 4. (IV) Fiscal policy was constrained in the sense that the authorities were now allowed to run a deficit (in the sense of the increase in government expenditures in any one year increasing at a faster pace than government revenues). However surpluses up to five per cent could be run; and

5. (V) The same balanced budget constraint operate as in IV with the requirmeent that the government had to contain budgetary surpluses not to exceed 2.5 per cent of the growth in revenues.

Given each of the above constraints, the optimal control model selected government expenditures (GEX) as the policy variable, i.e., the variable under the control of the Saudi authorities for the purpose of maximising the overall rate of growth in non-oil income over the 1965-85 period.

For each of the five constraints this optimization process implies a unique rate of growth in the money supply. In the context of the Bronfenbrenner and Modigliani framework examined above, these increases in the money supply were termed 'discretionary' policy. As with the Bronfenbrenner and Modigliani ex post analysis, the results obtained by examining the deviations of the optimal money supply from the ideal pattern were compared to those:

1. Obtained by simply increasing the money supply at a flat rate of 10 per cent; and

2. Those (in Bronfenbrenner's case) obtained through the adoption of a lag rule.

The results for the Bronfenbrenner test (Table 4) somewhat surprisingly suggest:

1. The general superiority of simple rules over (in this case) the use of optimally designed discretionary policy.

2. The lag rule turns out to be somewhat superior to the 10 per cent monetary increase rule both in terms of the standard deviation and the mean absolute deviation. 
Table 4.

SAUDI ARABIA: DEVIATIONS OF ALTERNATIVE MONETARY FISCAL POLICIES FROM IDEAL, OPTIMAL CONTROL SIMULATIONS, 1966-1985, BRONFENBRENNER MODEL

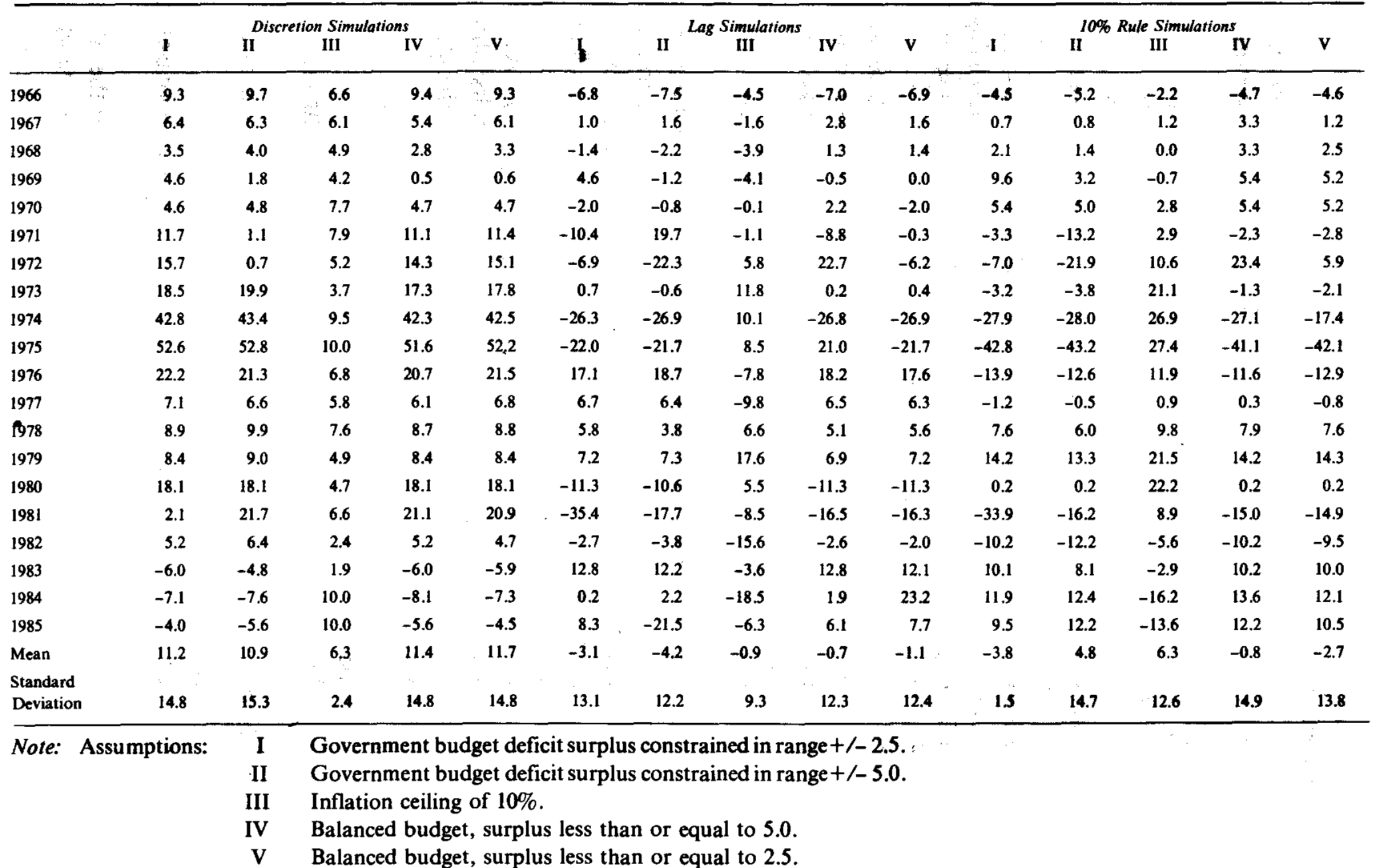


3. The best result in terms of stabilization is discretionary policy constrained to maintain a rate of inflation at or below 10 per cent per annum. Unfortunately this policy (of the five strategies considered here) produces by far the lowest overall (Table 5) rate of growth in non-oil Gross Domestic Product.

4. Surprisingly the widening of the constraints on the size of budgetary surpluses and/or deficits (runs II and IV versus I and V) produces at best only marginal improvements in stabilization, while at the same time sacrificing overall non-oil income growth.

Table 5.

SAUDI ARABIA: COMPARATIVE POLICY PERFORMANCE

\begin{tabular}{lccc}
\hline Simulation & $\begin{array}{c}\text { Average Growth in } \\
\text { Non-oil Income }\end{array}$ & $\begin{array}{c}\text { Average Rate } \\
\text { of Inflation }\end{array}$ & $\begin{array}{c}\text { Growth in } \\
\text { Money } \\
\text { Supply }\end{array}$ \\
\hline I & 11.4 & 11.1 & 25.1 \\
II & 11.2 & 10.9 & 25.7 \\
III & 4.2 & 6.2 & 9.9 \\
IV & 10.7 & 11.4 & 22.1 \\
V & 12.1 & 11.7 & 24.4 \\
10\% & 4.2 & 6.8 & 10.0 \\
Actual & 10.3 & 10.8 & 24.1 \\
\hline
\end{tabular}

Note: $\quad$ See Table 3 for simulation assumptions.

As with the earlier tests of ex post performance (Tables 1 and 2), ex ante Modigliani type tests performed (Table 6) on the optimal control simulations also tend to indicate the general superiority of a fixed monetary rule for the purpose of conducting Saudi Arabian macroeconomic policy.

\section{CONCLUSIONS}

In terms of the future, the results above indicate that Saudi Arabian authorities could obtain better overall rates of growth through the pursuit of better designed macroeconomic policies. i.e., despite the decline in oil revenues, there is some scope for increasing the overall rate of economic 
Table 6.

SAUDI ARABIA: DEVIATIONS OF ALTERNATIVE MONETARY FISCAL POLICIES FROM IDEAL, OPTIMAL CONTROL SIMULATION, 1966-1985, MODIGLIANI MODEL

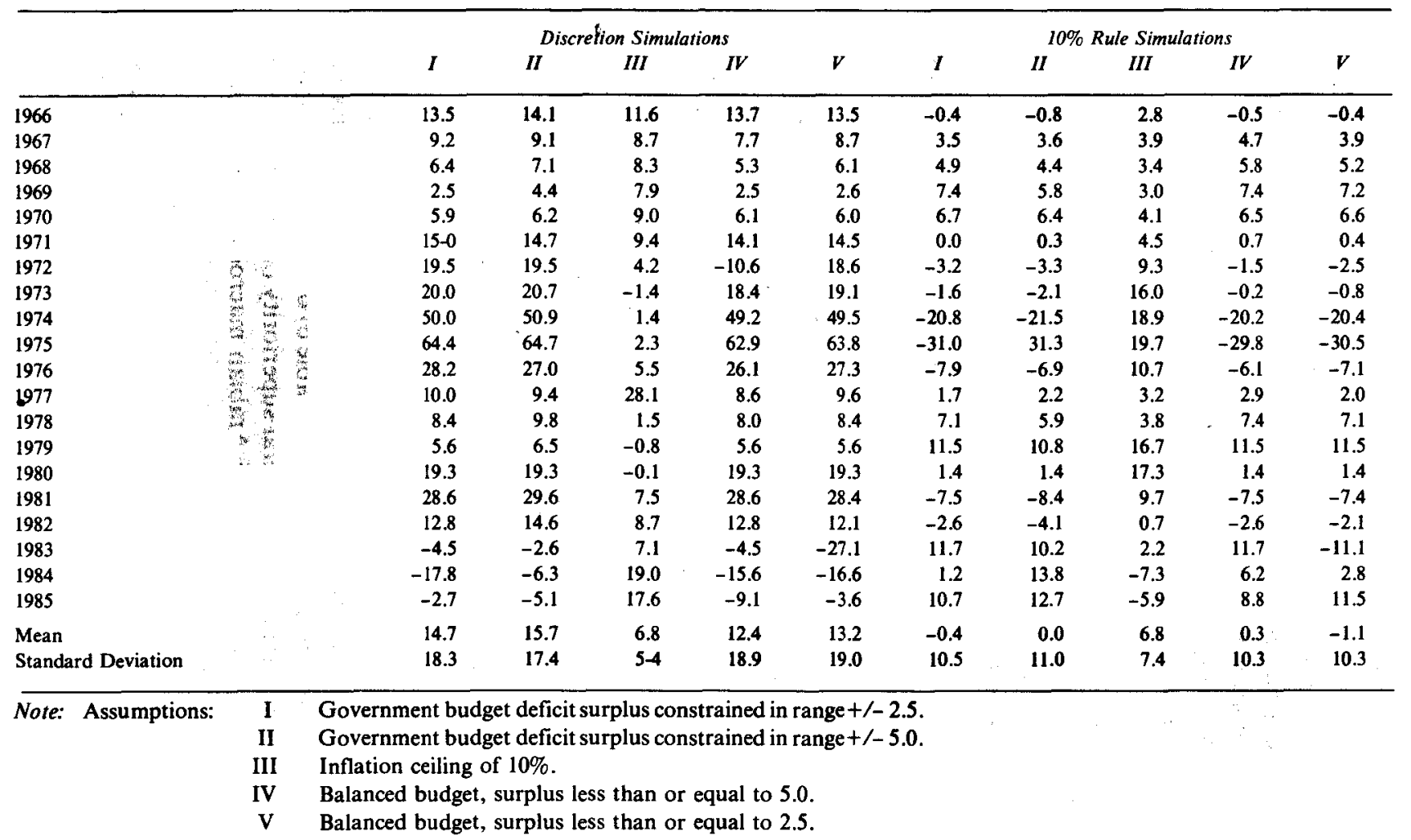


growth through the adoption of a macroeconomic strategy more constrained than those in effect in the past.

The conclusions as to the relative merits of fixed monetary rules for the conduct of Saudi Arabian macroeconomic policy are only intended to be suggestive with the burden of proof of discretionary policy placed on its advocates. The point of the exercises presented above was simply to illustrate how the rules of thumb might be used - not to suggest an optimal rule. It should also be stressed that rules of thumb are just that; they are not great principles to which the Saudi Arabian policy makers would always mechanically want to adhere. If economic events in the country clearly indicated the desirability of abandoning a rule, that option should be left open to the decision-makers. What the results favouring the application of rules do say is that Saudi Arabian policy makers should be made aware of the desirability of stability and continuity in the conduct of policy.

\section{NOTES}

1. Estimates were made using a Cochrane Orcutt iterative estimation procedure to correct for first order serial correlation. The variable RHO is the serial correlation parameter. Data is from the Saudi Arabian Monetary Fund. Annual Report (various issues).

\section{REFERENCES}

Al-Timimi, W.A. (1985) 'The Evolution of the Saudi Arabian Monetary System', Banca Nazionale Del Lavoro Quarterly Review No. 152, pp.77-83.

Bronfenbrenner, Martin (1961) 'Statistical Tests of Rival Monetary Rules'. Journal of Political Economy. Vol.69, pp.621-25.

Eshag, Eprime (1983) Fiscal and Monetary Policies and Problems in Developing Countries. Cambridge: Cambridge University Press.

Fekrat, M.A. (1979) 'Growth of OPEC-Type Economies: A Preliminary Theoretical Inquiry'. Economica Internationale, Vol.32, pp.77-87.

Friedman, M. and Schwartz, Anna (1963) A Monetary History of the United States. Princeton: Princeton University Press.

Keran, Michael and Al-Malik, Ahmed Abdullah(1979) 'Monetary Sources of Inflation in Saudi Arabia'. Federal Reserve Bank of San Francisco. Economic Review. pp.3-27.

Looney, Robert (1986) 'Socio-Economic Tradeoffs in Saudi Arabia's Five Year Plan', Socio-Economic PlanningsSciences, Vol.20, pp.181-192. 
Looney, Robert (1987) 'Scope for Policy in an Oil Based Economy: Mexican Stabilization Efforts in the 1970s'. Socio-Economic Planning Sciences. Vol.21, pp.167-76.

Modigliani, F. (1964) 'Some Empirical Tests of Rival Monetary Rules', Journal of Political Economy. Vol.72, pp.321-45, March 28, 1989.

Motamen, Homa (1979) Expenditure of Oil Revenue: An Optimal Control Approach with Applications to the Iranian Economy. New York: St. Martin's Press.

Morgan, David (1979) 'Fiscal Policy in Oil Exporting Countries, 197278' International Monetary Fund Staff Papers, Vol.26, pp.55-86.

Tavlas, G.S. and Ascheim, J. (1981) 'The Chicago Monetary Growth-Rate Rule: Friedman and Simons Reconsidered'. Banca Nazionale del Lavoro Quarterly Review. No.136, pp.75-89. 